\begin{tabular}{|c|c|c|}
\hline \multirow{2}{*}{ - } & $\begin{array}{l}\text { International Journal of Current Research in } \\
\text { Biosciences and Plant Biology }\end{array}$ & 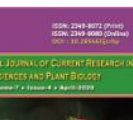 \\
\hline & Volume $7 \bullet$ Number 4 (April-2020) • ISSN: 2349-8080 (Online) & \\
\hline $\begin{array}{l}\text { EXCELLENT } \\
\text { PUBLISHERS }\end{array}$ & Journal homepage: $\underline{w w w . i j c r b p . c o m}$ & \\
\hline
\end{tabular}

\title{
Sensitivity of primary cells from kidneys and testicles of lambs and goats to the lumpy skin disease virus
}

\author{
B. Sh. Myrzakhmetova* and L. B. Kutumbetov \\ Ministry of Education and Science of the, Science Committee, «Research Institute for Biological Safety Problems» \\ Gvardeiskiy village, Kordai district, Republic of Kazakhstan \\ *Corresponding author; e-mail: rib.sp@biosafety.kz
}

\begin{tabular}{ll}
\hline Article Info & ABSTRACT \\
\hline $\begin{array}{l}\text { Date of Acceptance: } \\
\text { 20 March 2020 }\end{array}$ & $\begin{array}{l}\text { The results of a comparative analysis of sensitivity to the virus of lumpy skin disease } \\
\text { indicate that a cell culture from the testicular tissue of lambs and goats is used as a } \\
\text { producer substrate for obtaining the most active viral biomass of the indicated } \\
\text { pathogen. The use of these cell cultures allows for a short time to obtain the biomass } \\
\text { of the virus of lumpy skin disease in the highest titers. The titer of the virus } \\
\text { o6 April 2020 }\end{array}$ \\
$\begin{array}{l}\text { reproduced in the testicular cell culture, will make it possible to use the specified } \\
\text { cultural viral mass for the manufacture of vaccine and diagnostic preparations. }\end{array}$ \\
$\begin{array}{l}\text { Primary cells } \\
\text { Transplantable cells } \\
\begin{array}{l}\text { Lumpy skin disease } \\
\text { Producer substrate }\end{array}\end{array}$ \\
\begin{tabular}{l} 
Proliferation \\
\hline
\end{tabular}
\end{tabular}

\section{Introduction}

Viruses of the genus Capripoxvirus of the family Poxviridae have strict species pathogenicity and their in vitro reproduction is successful in cell cultures obtained or derived from organs and tissues of animals susceptible to these pathogens (Shumilova et al., 2017; Zhou et al., 2004; Kutumbetov, 2010; Maykhin, 2003). There is the possibility of re-adaptation of these viruses to reproduction in some cell cultures, which are obtained from the organs of another animal species that is not susceptible to the specified pathogen (Nisanova et al., 2018; Kalra and Sharma 1981; Balysheva et al., 2017; Binepal et al., 2001). The virus of lumpy skin disease is the third representative of the genus Capripoxvirus, and this pathogen naturally affects only cattle (Syurin, 1998). By analogy with sheep pox and goat pox viruses, this pathogen, by its nature, must be reproduced in vitro only in cell cultures derived from cattle organs. However, according to some authors, the virus of lumpy skin disease has the ability to reproduce, in addition to the culture of cells from the organs of cattle, and in the culture of cells prepared from the organs of lambs and goats (Tuppurainen et al., 2005; Babiuk et al., 2007; Jassim and Keshavamurthy, 1981).

The ability to replicate in the culture of cells from the organs of these animal species in some countries is used in the production technology of 
the vaccine against lumpy skin disease (Tuppurainen et al., 2014; Kutumbetov et al., 2019). However, the comparative sensitivity of cells obtained from one or another organ of these animals is not given in the literature.

The aim of this work was to assess the sensitivity of primary cell cultures obtained from testicles and kidneys of lambs and goats.

\section{Materials and methods}

The donors of testicles and kidneys were lambs and goats 1-3 months of age. Testicles were obtained by aseptic removal of them from the body of a donor animal by a surgical method. Animals, after removal of the testicles were kept in the room until recovery.

An isolated organ was transported in a Hanks solution with antibiotics and in the laboratory they were mechanically cleaned of connective tissues, and then trypsinized in a solution of $0.25 \%$ trypsin. Before trypsinization, the testicular tissue was cut into small, homogeneous pieces measuring 50-60 $\mathrm{mm}^{3}$ (approximately $3-4 \times 3-4 \times 3-4 \mathrm{~mm}$ ). Trypsinization was carried out according to the standard technique (Syurin 1966; Hay, 1988; Mironova, 1992; Birger, 1982). The action of trypsin was neutralized by the blood serum of cattle used in the composition of the nutrient medium for growing cells. Cells were seeded at concentrations of $100-200 \times 10^{3}$ cells $/ \mathrm{cm}^{3}$. As a growth medium, a nutrient medium according to the prescription Eagle with content of $10 \%$ serum of cattle was used. The number of cells was determined by counting in a Goryaev chamber after staining with trypan blue solution.

Renal cells were obtained from the kidneys of lambs and goats after their slaughter by total bleeding. Trypsinization, seeding and culturing of cells from the kidneys was carried out by analogy with testicular tissue.

The suspension of the primary cells of the testicles and kidneys was sown in flask with a capacity of 1.5 $\mathrm{dm}^{3}$ in a volume of $120+10 \mathrm{~cm}^{3}$ and cultivated at a temperature of $37^{\circ} \mathrm{C}$ in an incubator. After 24 hours, the culture fluid in the flask was removed and fresh nutrient medium was added with $10 \%$ serum of cattle. Cell status was monitored daily by microscopy. After cell adhesion and the formation of a monolayer, the cell culture of each species was infected with the lumpy skin disease virus with the same multiplicity. The cultivation of infected cell cultures in flask was carried out at a temperature of $37^{\circ} \mathrm{C}$ until the development and maximum development of CPE (cytopathogenic effect). At the time of maximum lesion of the monolayer, the cell culture with the virus was frozen for 18 hours. It was then thawed at room temperature, thoroughly mixed, and the titer of the virus was set in the contained flask. In the absence of a CPD during the initial infection, blind passage of the virus was performed. For this, the contents of the flask, in which there was no CPD for up to 7 days, were frozen at a temperature of minus $40^{\circ} \mathrm{C}$, then thawed and the resulting suspension in a volume of $10 \mathrm{~cm}^{3}$ was transferred to a fresh monolayer of homologous cell culture. The cultivation and observation of the infected cell culture of the second passage was carried out as in the first passage.

Virus titration was carried out on a multilayer cell culture from testicles and kidneys of lambs and goats, prepared in penicillin vials. Each virus sample obtained by reproduction in one type of cell culture was titrated in parallel on homologous and testicular cell cultures. The presence of the virus was determined by its CPD in cell culture, and the titer was calculated by Reed and Mench (1938).

\section{Results}

The testicular cells of lambs and goats were similar in morphology and were fibroblast-like, and the renal cells of both animal species were epithelial in morphology. Primary trypsinized cells did not adhere completely. Up to 30\% of seeded cells were attached to the glass surface, which then, as they proliferated, formed a monolayer for 48-72 hours. The proliferative activity of fibroblast-like cells was comparatively higher than that of epithelial-like cells. The latter formed a monolayer at 72-96 hours after sowing.

The sensitivity to the virus of lumpy skin disease of primary cell cultures varied significantly depending on the type of cells and their donor. In a morphological evaluation carried out using microscopy, the lumpy skin disease virus caused an active $\mathrm{CPE}$ (cytopathogenic effect) in relation to 
the cell culture obtained from the testicular tissue of the lambs. The cytopathogenic effect of the virus in this cell culture was characterized by the appearance of swollen (edematous) cells located in groups on different parts of the monolayer 72-96 hours after the pathogen inoculation, and subsequently, all remaining monolayer cells underwent such a change for 120-144 hours. After 120-144 hours, the affected cells were gradually torn away from the glass surface or degenerated, rounding and tearing.

Degeneration of the affected cells led to loosening of the monolayer of cells with the formation of intercellular voids - "windows". Further cultivation of cells with the virus led to even greater destruction of the monolayer of cells with a decrease in the number of adhesive. By 9-10 days after infection, single cells remained on the adhesion surface (inner surface of the culture flask).

The cytopathogenic effect of the virus of lumpy skin disease in a culture of cells from testicular tissue of the goats reminded the lesion caused by this virus in the culture of cells of testicles of lambs. However, in the culture of testicle cells of goats, the $\mathrm{CPE}$ appeared only at the second passage and with less activity in the development of pathology.
In the culture of cells from the kidneys of lambs and goats, the CPE of the virus appeared on the 56th day after infection, and this process was characterized by the formation of single and groups of rounded cells that refract light well. In the monolayer of the lamb's kidney cell culture, the viral CPE appeared in the first passage, and kidney cell cultures only in the second passage. The cytopathogenic activity of the virus was greater in lamb's kidney cell culture than in goat kidney cells.

The activity of the development of CPE in the monolayer of the culture of epithelial-like cells was significantly lower than the activity of the development of this pathology in the monolayer of the culture of fibroblast-like cells.

\section{Discussion}

The results of a visual assessment of the sensitivity of the primary cell culture obtained from different organs of two animal species were confirmed by the titer data of the virus reproduced in these biological models / substrates producing at the same multiplicity of infection. The titration data of the culture suspension obtained after infection of the lumpy skin disease virus with a monolayer cell culture from the tissues of the testicles and kidneys of lambs and goats is shown below (Table 1).

Table 1. The titer of the virus of lumpy skin disease reproduced in the primary cell culture prepared from testicles and kidneys of lambs and goats.

\begin{tabular}{llll}
\hline Cell culture & $\begin{array}{l}\text { Infectious dose of the } \\
\text { virus TCD }\end{array}$ & $\begin{array}{l}\text { Dotes of maximum } \\
\text { development of CPE, day }\end{array}$ & $\begin{array}{l}\text { Virus titer, } \\
\text { TCD }_{\mathbf{5 0} / \mathbf{s m}^{3}}\end{array}$ \\
\hline LT & $0.05-0.07$ & 6 & $10^{6.17 \pm 0.34}$ \\
LK & $0.05-0.07$ & 9 & $10^{4.87 \pm 0.73}$ \\
GT & $0.05-0.07$ & 7 & $10^{5.33 \pm 0.89}$ \\
GK & $0.05-0.07$ & 12 & $10^{3.13 \pm 1.09}$ \\
\hline
\end{tabular}

Note: LT - lambs testicles; LK - lambs kidneys; GT - goats testicles; GK - goats kidneys.

As can be seen from the data in Table 1, the CPD of the lumpy skin disease virus with the same multiplicity of infection developed most rapidly and reached its maximum value in a relatively short time in the cell culture of LT, which did not exceed 6 days. In other cell cultures, the maximum development of CPE was noted at a later date than in LT. However, the rate of development of the
CPE in the culture of fibroblast-like cells (testicles of lambs and goats) was significantly higher than the rate of development of a similar pathology noted in the culture of epithelial cells (kidneys of lambs and goats).

Morphological indicators of the rate of development of $\mathrm{CPE}$ were confirmed by virus titers 
in each cell culture. The highest titer of the virus, equal to $10^{6.17 \pm 0.34} \mathrm{TCD}_{50} / \mathrm{cm}^{3}$, was observed in $\mathrm{LT}$ cell culture, in which the virus CPE developed actively and reached the maximum value in the shortest time of 6 days, affecting 90\% or more of the monolayer cells . A slightly lower titer of the virus, equal to $10^{5.33} \pm 0.89 \mathrm{TCD}_{5 \mathrm{o} / \mathrm{cm}^{3}}$, was observed in the culture of GT cells, in which the rate of development of the CPD was somewhat slower and reached its maximum one day later than in LT. In cell cultures from the testicular tissue of both animal species, the rate of development of the $\mathrm{CPE}$ of the virus of lumpy skin disease exceeded the similar indicator of viral pathology observed in cell cultures from the kidneys of lambs and goats. In the last two substrates-producers, the CPE of the virus was characterized by focal lesion of the cell monolayer and not more than $30-50 \%$ of all cells underwent pathology until the end of the observation, which lasted 12 days.

According to the rate and nature of the development of $\mathrm{CPE}$, the lowest titers of the virus were observed in cell cultures prepared from the kidneys of lambs and goats, the average titers of the virus in which did not exceed $10^{4.87} \pm 0.73-$ $10^{3.13} \pm 1.09 \mathrm{TCD}_{50 / \mathrm{cm}^{3}}$. The virus titer in the culture of epithelial-like cells was lower in that in which the CPD developed more slowly. Correspondingly, at the rate of reaching the maximum CPD values of 9 days in the culture of the cells of the LK, the virus titer was $10^{4.87 \pm 0.73} \mathrm{TCD}_{50} / \mathrm{cm}^{3}$, and in the culture of the cells of the GK, in which the maximum indicators of the viral lesion reached after 12 days, the titer of the virus did not exceed $10^{3}{ }^{13 \pm} 1.09$ TCD $50 / \mathrm{cm}^{3}$. The last indicator of the titer of the virus in more than 50 times lower than the same value in the culture of cells of the LK.

\section{Conclusion}

Thus, evaluating the rate of development of CPD in cell cultures prepared from different organs of two animal species, the virus titer accumulated in the culture suspension can be concluded that the primary cell culture obtained from lamb's testicles has the highest sensitivity to the virus of lumpy skin disease. A slightly less sensitive to this virus has a cell culture obtained from testicles of goats.

Cell cultures prepared from the kidneys of lambs and goats are significantly inferior in sensitivity to cell cultures prepared from testicles of the same animal species.

The results of a comparative analysis of the sensitivity to the virus of lumpy skin disease indicate that a cell culture from the testicular tissue of lambs and goats is used as a producer substrate for obtaining the most active viral biomass of this pathogen. The use of these cell cultures allows for a short time to obtain the biomass of the virus of lumpy skin disease in the highest titers. The titer of the virus reproduced in the testicular cell culture, will make it possible to use the specified cultural viral mass for the manufacture of vaccine and diagnostic preparations.

\section{Conflict of interest statement}

Authors declare that they have no conflict of interest.

\section{References}

Babiuk Sh., Parkyn G., Copps J., Larence J.E., Sabara M.I., Bowden T.R., Boyle D.B., Kitching R.P. Evaluation of an ovine testis cell line (OA3.Ts) for propagation of capripoxvirus isolates and development of an immunostaining technique for viral plaque visualization. Journal Vet Diagn Invest 19:486491 (2007).

Balysheva V.I., Zhivoderov S.P., Pivova E.Yu. et al. Permissibility of cell cultures of various origin during cultivation of lumpy skin disease virus. Agricultural biology. 2017. Volume 52. No. 6. p.1265-1272.

Binepal Y.S., Ongadi F.A., Chepkwony J.C. Alternative cell lines for the propagation of lumpy skin disease virus. Onderstepoort Journal of Veterinary Research. 68:151-153 (2001).

Birger, M.O. Handbook of microbiological and virological research methods [Isolation of viruses in cell cultures and methods for their indication] / M.O. Birger, E.A. Witch, V.V. Lord - M .: Kolos, 1982.- 358 p.

Hay R.J. The seed stock concept and quality control for cell lines. 1988. Anal Biochem 17:225-237.

Jassim F.A., Keshavamurthy B.S. Cytopathic changes caused by sheep pox virus in secondary culture of lamb testes cells. 1981. 
Bull Off Int Epizoot 93:1401-1410.

Kalra S.K., Sharma V.K. Adaptation of Jaipur strain of sheeppox virus in primary lamb testicular cell culture. 1981. Indian J Exp Biol 19:165-169.

Kutumbetov L.B. Technological basis for the manufacture of vaccines against sheep pox, smallpox goats and smallpox birds [Cultivation of animal pox viruses and birds]: dis ... dr. vet sciences: 16.00.03: it is protected 26.08.10: utv. 16.06.11 / Kutumbetov L.B. - A., 2010. - p. 340.

Kutumbetov LB, Myrzakhmetova B.Sh., Orynbaev M.B. The strain "RIBSP-2019 / K" lumpy skin disease virus type "Neethling" used to control the immunogenicity of live and inactivated vaccines against lumpy skin disease in cattle. Application for the grant of a patent of the Republic of Kazakhstan for an invention. Registration number 2019 / 0814.1

Maykhin K.T. The manufacturing technology of the vaccine against sheep pox from the attenuated KazNIVI strain using a transplantable cell culture [Maintenance of the substrate for the reproduction of sheep pox viruses]: disc ... candidate of science ... 16.00.03: approved 12.08.03: approved. 06/09/04 / Maykhin K.T. - A., 2003.- 97 p.

Mironova L.L. The experience of obtaining and using primary and transplantable cell cultures // Cultivation of animal and human cells: Abstracts. - Pushchino, 1992. - V. 96-103.

Nisanova R.K., Rystaeva R.A., Kerimbaev A.A., Omarova Z.D., Orynbaev M.B. Choice of a sensitive system for the cultivation of the virus of lumpy skin disease virus of cattle //
"Research, results". No. 4 (80) 2018. - p. 2632.

Reed L., Muench H. A simple method of estimating fifty percent endpints // Amer.J. Hyg. - 1938. p.27. - P. 493-497.

Shumilova I.N., Kononova S.V., Manin LB, Koropova N.V., Kononov A.V. The cultivation of the lumpy skin disease virus in cattle in transplantable cell culture lines // Laboratory practice. - M. 2017. - p.53-57.

Syurin, V.N. Guide to Veterinary Virology [Cultivation of animal tissue cells] - M. Kolos, 1966. - $680 \mathrm{p}$.

Syurin, V.N.Viral diseases of animals [Lumpy skin disease] / V.N. Syurin, A.Ya. Samuilenko, B.V. Soloviev, N.V. Fomina. - M.: VNITIBP, 1998. $928 \mathrm{p}$.

Tuppurainen E.S., Venter E.H., Coetzer J.A. The detection of lumpy skin disease virus in samples of experimentally infected cattle using different diagnostic techniques. Onderstepoort J. Vet.Res. 2005; 72 (2): 153-164.

Tuppurainen E.S. M., Pearson C. R., BachanekBankowska K., Knowles N. J., Amareen S., Frost L., Mertens P. P. C. Characterization of sheep pox virus vaccine for cattle against lumpy skin disease virus // Antiviral Research. - 2014. - p. 109 (1). - P. 1 - 6. https://doi.org/10.1016/j.antiviral.2014.06.06. 009.

Zhou J.S., Ma H.L., Guo Q.S. Culturing of ovine testicular cells and observation of pathological changes of the cell inoculated with attenuated sheep pox virus. 2004. Chinese J Vet Sci Technol 34:71-74.

\section{How to cite this article:}

Myrzakhmetova, B. Sh., Kutumbetov, L. B., 2020. Sensitivity of primary cells from kidneys and testicles of lambs and goats to the lumpy skin disease virus. Int. J. Curr. Res. Biosci. Plant Biol. 7(4), 1-5.

doi: https://doi.org/10.20546/ijcrbp.2020.704.001 